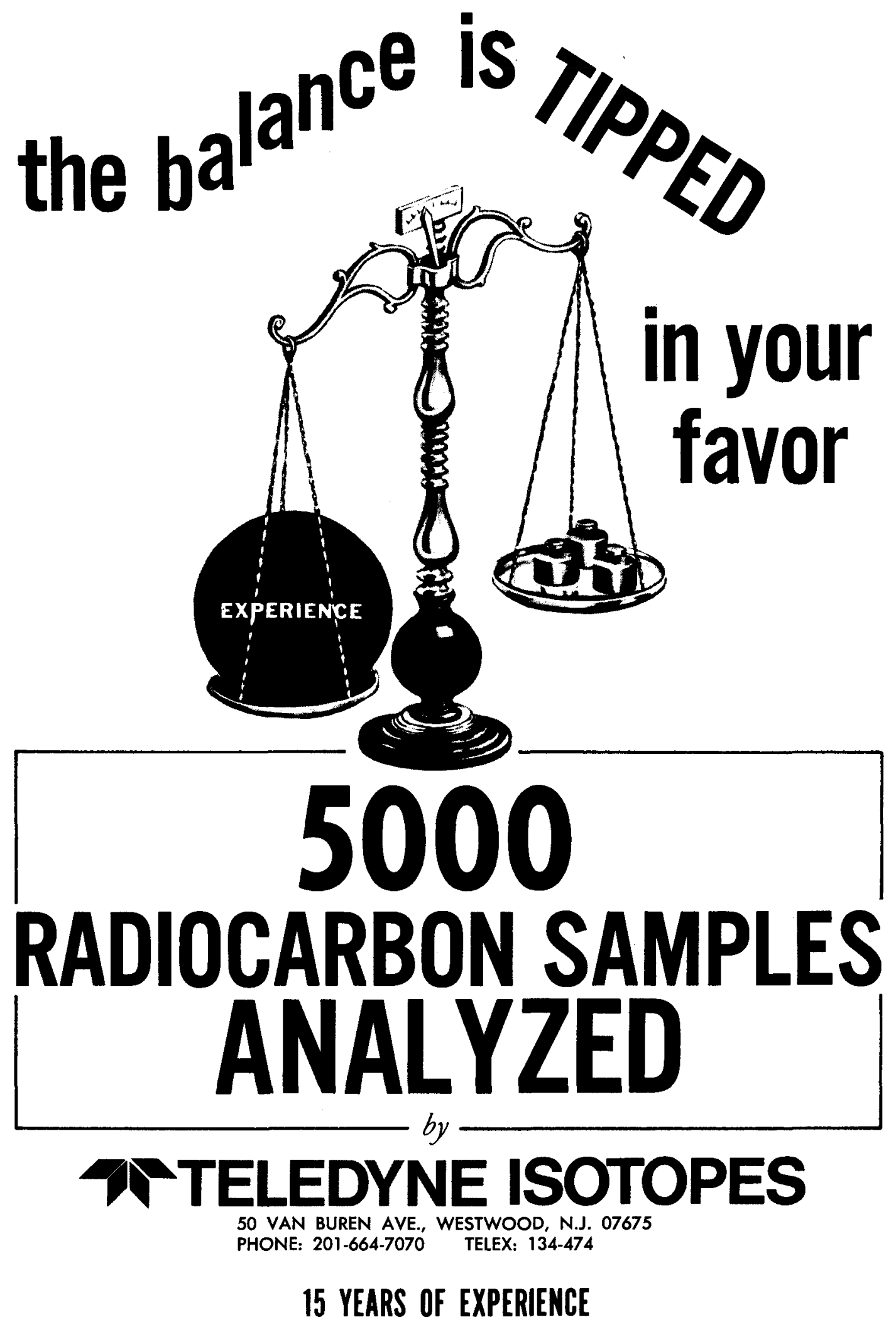




\section{WHAT'S THE BEST WAY TO GET A DATE?}

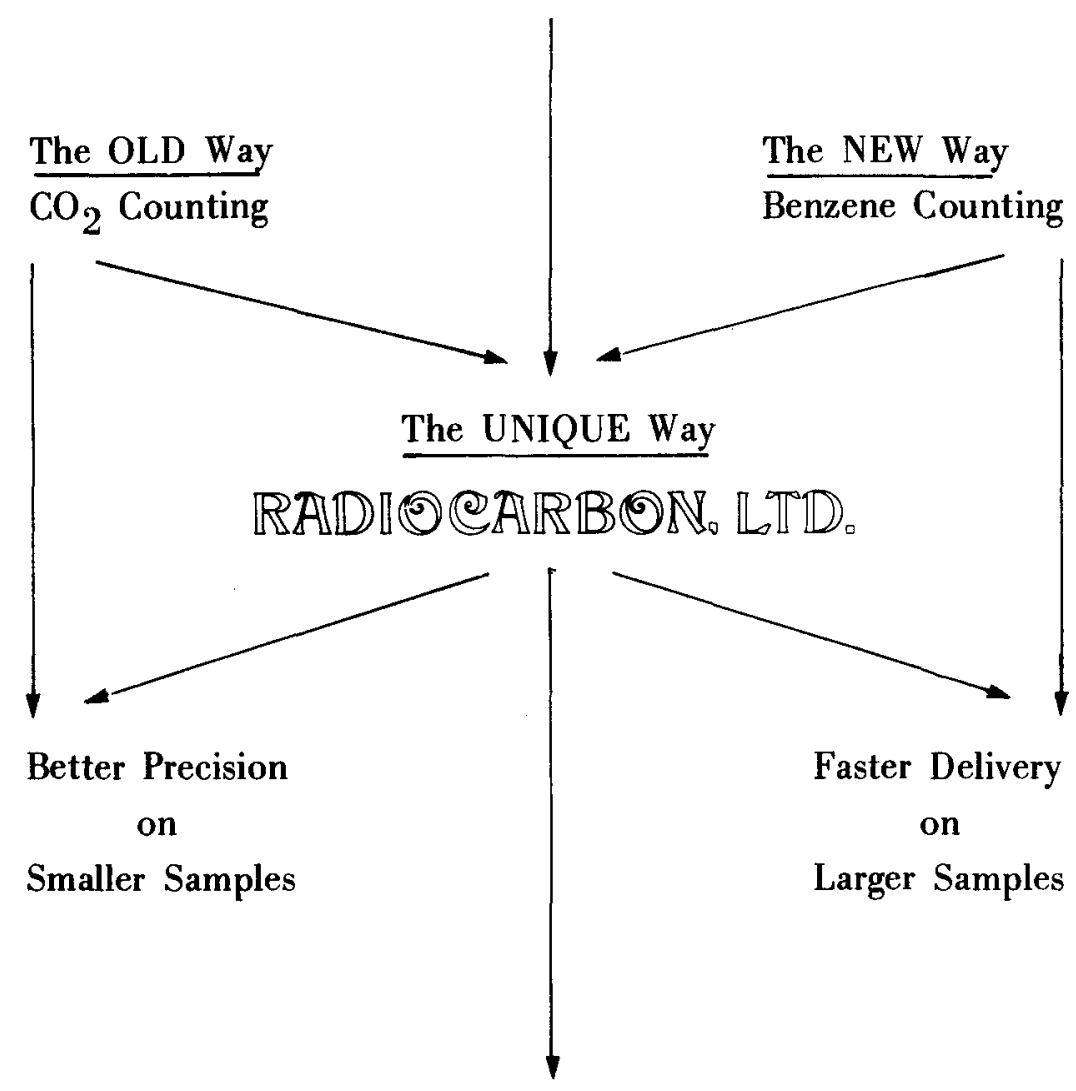

For more information regarding the unique service provided by the benzene-counting and the $\mathrm{CO}_{2}$ - counting facilities of Radiocarbon, Ltd., where delivery of results can be as fast as two to three weeks, write directly to Charles S. Tucek, or telephone.

\section{RADIOCARBON. LTD.}




\title{
GUIDE TO DEPARTMENTS OF ANTHROPOLOGY 1973-74
}

The issue for

academic year 1973-74 will be available in September. Each year the Guide is expanded and updated to include the growing number of departments of anthropology in colleges, universities and museums. For anthropologists and for prospective students of anthropology, this comprehensive listing is an invaluable source of specific information not available elsewhere. The AAA no longer distributes the Guide free to any category of membership.

$\$ 4.00$ (paper)

(AAA individual members, \$2.50)

address all orders to:

\section{AMERICAN ANTHROPOLOGICAL ASSOCIATION}

\author{
Publications Department
}

1703 New Hampshire Avenue NW • Washington, DC 20009

payment must accompany orders 
President: DOUGLAS W. SCHWARTZ, School of American Research, P.O. Box 1554, Santa Fe, New Mexico 87501.

President-elect: CHARLES R. McGIMSEY III, Department of Anthropology, University of Arkansas, Fayetteville, Arkansas 72701.

Secretary: RICHARD E. W. ADAMS, Department of Anthropology, 4242 Piedras Drive East, Suite 250, University of Texas at San Antonio, Texas 78228.

Treasurer: FRED WENDORF, Department of Anthropology, Southern Methodist University, Dallas, Texas 75222.

Editor: EDWIN N. WILMSEN, Museum of Anthropology, University Museums Building, University of Michigan, Ann Arbor, Michigan 48104.

Editor-elect: FRANK HOLE, Department of Anthropology, Rice University, Houston, Texas 77001.

Executive Committee Members: JAMES J. F. DEETZ (to 1974), Department of Anthropology, Brown University, Providence, Rhode Island 02912; CYNTHIA IRWIN-WILLIAMS (to 1974), Department of Anthropology, Eastern New Mexico University, Portales, New Mexico 88130; GEORGE C. FRISON (to 1975), Department of Anthropology, Box 3431, University of Wyoming, University Station, Laramie, Wyoming 82070; GEORGE L. COWGILL (to 1975), Department of Anthropology, Brandeis University, Waltham, Massachusetts 02154.

\section{EDITORIAL STAFF OF amERICan antiquity}

Editor: EDWIN N. WILMSEN, Museum of Anthropology, University Museums Building, University of Michigan, Ann Arbor, Michigan 48104.

Ediror-elect: FRANK HOLE, Department of Anthropology, Rice University, Houston, Texas 77001.

Associate Editor for Memoirs: H. MARTIN WOBST, Department of Anthropology, University of Massachusetts, Amherst, Massachusetts 01002.

Associate Editor for Reviews: FRED PLOG, Department of Anthropology, State University of New York, Bingham ton, New York 13901.

Associate Editor for Current Research: MARY ELIZABETH KING, Texas Tech Museum, P.O. Box 4499, Lubbock, Texas 79409.

Associate Editor for Current Affairs: CHARLES R. McGIMSEY III, Department of Anthropology, University of Arkansas, Fayetteville, Arkansas 72701.

Production Editor: ELSA LOUISE VORWERK

Circulation Manager: RONNIE McDANIEL

AMERICAN ANTIQUITY publishes original papers on the archaeology of the New World and closely related subjects. Articles, Reports, and Comments should be submitted to the Editor, memoirs should be submitted to the Associate Editor for Memoirs, publications for review to the Associate Editor for Reviews, and information for "Current Research" to the Associate Editor for Current Research. AMERICAN ANTIQUITY is not available for exchange.

AMERICAN ANTIQUITY is published quarterly in January, April, July, and October by the Society for American Archaeology. Second-class postage paid at Washington, D.C. Subscription is by membership in the Society for American Archaeology. Annual dues for individual members are $\$ 15.00$; for institutional members, $\$ 20.00$. Special membership rates of $\$ 10.00$ are available to students and to the members in Latin America and overseas. Address requests for individual or institutional membership, instructions for change of address, or complaints about subscription fulfillment to Society for American Archaeology, 1703 New Hampshire Avenue, N.W., Washington, D.C. 20009. See inside back cover for information on ordering back issues of AMERICAN ANTIQUITY and other publications of the Society that are still in print. Copyright (c) 1973 by the Society for American Archaeology. All rights reserved. Printed in U.S.A.

\section{NOTICE TO AUTHORS}

All manuscript material must be typed double-spaced on one side of sheet only. Use white non-corrasable bond. Submit original plus two copies. Include an abstract of less than 150 words that specifically refers to text material. Upon publication, abstracts will be submitted to $A$ bstracts in Anthropology for inclusion in that series. Footnotes are not permitted. Text citations are set in parentheses, e.g. (Author 1970:100). References are listed alphabetically by author and chronologically by year, For details of manuscript organization, form of reference citation, and punctuation, etc., examine thits issue. Citations in a review are placed entirely between parentheses in the text. All illustrations must be submitted as black on white drawings or as glossy prints and must not exceed $9 \times 12$ in. Number all figures consecutively and provide a caption for each. Tables should be typed on separate pages, numbered in sequence, and given headings. Large tables should be photographically reduced to fit one or more pages. Radiocarbon ages are given in the following forms: $11,950 \pm 100$ radiocarbon years: 10000 B.C. (Z-200), if not previously cited; $1,000 \pm 100$ radiocarbon years: A.D. 950 (Smith 1960), if previously cited. (See AMERICAN ANTIQUITY 36:246-249 for more detailed information on style.) 


\section{CONTENTS}

United States "Imperialism" and Latin American Archaeology

Clifford Evans and Betty J. Meggers

\section{ARTICLES}

Economic Aspects of Commercial Archaeology in Costa Rica

Spatial Analysis of Occupation Floors I: Application of Dimensional Analysis of Variance

Dwight B. Heath

Location Analysis of Prehistoric Maya Sites in Northern British Honduras

Robert Whallon, Jr. 266

Painting, Writing, and Polity in Teotihuacan, Mexico

Ernestene L. Green 279

John Ladd, 1923-1971

Clara Millon 294

Gordon R. Willey 315

\section{REPORTS}

The Pillage of Prehistory

Statistical Tests of Spatial Association in the Locations of Tool Types

Iron Utilization by Thule Eskimos of Central Canada

Payson D. Sheets 317

X-Ray Diffraction Analysis of Prehistoric Pottery

Experimental Archaeology: A New Outlook

COMMENT

Reply to Kautz

A Method for Counting Ceramic Rim Sherds

Thomas $F$. King 351

B. J. Egloff 351

CURRENT RESEARCH

\section{REVIEWS}

Winters: The Riverton Culture: A Second Millennium Occupation in the Central Wabash Valley

Nelson: The Sunset Creek Site (45-KT-28): and Its Place in Plateau Prehistory

Rohn: Mug House: Mesa Verde National Park-Colorado

James $E$. Fitting 368

Ritter, Schulz, and Kautz: Papers on California and Great Basin Prehistory

Roderick Sprague Robert C. Euler

Watson, Leblanc, and Redman: Explanation in Archaeology: An Explicitly

Phillips: Archaeological Survey in the Lower Yazoo Basin, Mississippi, 1949-1955

Benson: Dumbarton Oaks Conference on Chavin Gardiner F. Dalley 371

Robert L. Schuyler 372 James B. Griffin 374 Craig Morris 380 